\title{
PEMETAAN GEOMORFOLOGI TERUMBU KARANG PULAU TUNDA MENGGUNAKAN KLASIFIKASI BERBASIS OBJEK
}

\section{CORAL REEF GEOMORPHIC MAPPING OF TUNDA ISLAND USING OBJECT BASE CLASSIFICATION}

\author{
Fahriansyah $^{1}$, Jonson Lumban Gaol' ${ }^{2}$, James P. Panjaitan ${ }^{2}$ \\ ${ }^{1}$ Program Studi Teknologi Kelautan, Sekolah Pascasarjana, \\ ${ }^{2}$ Depertemen Ilmu dan Teknologi Kelautan, \\ Fakultas Perikanan dan Ilmu Kelautan, Institut Pertanian Bogor \\ Korespondensi: fahriansyahmrg@gmail.com
}

\begin{abstract}
Mapping of coral reefs geomorphic in Tunda Island has not been done before using an object-based image classification. This mapping can be used as the basic of information to planning and area development towards the optimum utilization such as marine ecotourism area. This study aims to mapping coral reef geomorphic zone of Tunda Island using object base classification. Data analysis using multispectral image Worldview-2 with data acquisition of August 25, 2013 and bathymetric profiles. The classification using of multiresolution segmentation. The classification is divided into two levels of classification. Level 1 segmentation using parameter of scale 200, shape 0.6 and compactness 0.4 . Level 2 Segmentation using parameter of scale 30 , shape 0.6 and compactness 0.4 . The classification object segmentation able to produce a map with high accuracy at every level. The classification accuracy of Level 1 is $97 \%$ and level 2 is $91 \%$.
\end{abstract}

Keyword: Geomorphic zone, Object base classification, Tunda Island

\begin{abstract}
ABSTRAK
Pemetaan zona geomorfologi terumbu karang di Pulau Tunda ini belum pernah dilakukan khususnya menggunakan klasifikasi citra berbasis objek. Hasil pemetaan ini dapat digunakan sebagai dasar informasi perencanaan dan pengembangan suatu kawasan menuju pemanfaatan yang optimal seperti contoh pemanfaatan sebagai kawasan ekowisata bahari. Penelitian ini bertujuan untuk memetakan zona geomorfologi terumbu karang Pulau Tunda dengan menggunakan klasifikasi berbasis objek. Bahan analisis menggunakan citra multispektral Worldview-2 dengan akuisisi data tanggal 25 Agustus 2013 dan profil batimetri. Klasifikasi memakai algoritma segmentasi multiresolusi. Klasifikasi dibagi kedalam 2 level klasifikasi. Parameter klasifikasi level 1 menggunakan scale sebesar 200, shape 0.6 dan compactness 0.4. Segmentasi level 2 menggunakan scale 30, shape 0.6 dan compactness 0.4. Klasifikasi segmentasi objek ini mampu menghasilkan peta dengan tingkat akurasi yang tinggi pada setiap level. Akurasi klasifikasi level 1 adalah sebesar 97\% dan level 2 sebesar $91 \%$
\end{abstract}

Kata kunci: Klasifikasi berbasis objek, Pulau Tunda, Zona geomorfologi 


\section{PENDAHULUAN}

\section{Latar belakang}

Pulau Tunda merupakan salah satu gugusan pulau dari 17 pulau di Kabupaten Serang yang termasuk dalam program pengembangan perekonomian pulau-pulau kecil di Indonesia (Dirjen KP3K-KKP 2012). Pulau Tunda memiliki ekosistem terumbu karang yang beragam dan banyak ditemukan hidup di zona outer reef flat mengarah ke zona reef slope.

Penelitian terkait zona geomorfologi terumbu karang sudah banyak dilakukan seperti yang dilakukan oleh Phinn et al. (2011); Roelfsema et al. (2013); Zhang et al. (2013); Anggoro et al. (2015). Pemetaan zona geomorfologi terumbu karang di Pulau Tunda khususnya menggunakan klasifikasi citra berbasis objek belum pernah dilakukan. Hasil pemetaan ini dapat digunakan sebagai dasar informasi perencanaan dan pengembangan suatu kawasan menuju pemanfaatan yang optimal seperti contoh pemanfaatan sebagai kawasan ekowisata bahari.

Zona geomorfologi terumbu karang merupakan wilayah di kawasan ekosistem terumbu karang yang menempati suatu ruang meliputi lagoon, reefflat, reef crest, dan reef slope (Blanchon, 2011). Geomorfologi terumbu karang mengandung potensi kekayaan informasi ekologi yang mampu diakses jika hubungan antara morfologi dan ekologi dapat diterjemahkan (Blakeway $\&$ Hamblin 2015). Pemetaan geomorfologi terumbu karang memberikan informasi kunci untuk ilmuwan dan pemegang kepentingan tentang distribusi, luas dan struktur bentangan alam karang (Leon et al. 2012).

Teknologi penginderaan jauh sangat efektif pemanfaatannya dari segi biaya dan waktu untuk memantau perubahan dan manajemen sumberdaya alam khususnya objek perairan dangkal dan hutan mangrove (Mumby et al. 1999; Green et al. 2000; Maeder et al. 2002; Lillesand et al. 2004; Zhi-gang et al. 2008; Tamondong et al. 2013). Data satelit penginderaan jauh juga telah mengalami peningkatan kualitas yang baik mencakup resolusi spektral, resolusi temporal, resolusi spasial serta peningkatan kualitas sensor radiometrik.

Kebutuhan data citra resolusi tinggi dalam pengelolaan lingkungan tropis juga telah meningkat seiring dengan berkembangnya kegiatan antropogenik di wilayah pesisir (Chauvad et al. 1998). Meningkatnya kualitas dan resolusi citra, linear dengan kemampuannya untuk memetakan objek di permukaan bumi serta mampu menginterpretasi kelaskelas yang ditentukan dengan sangat baik. Namun, masih terdapat beberapa kelemahan khususnya dalam memetakan kolom perairan. Pancaran gelombang elektromagnetik dari sensor satelit yang memasuki kolom perairan tidak selalu sempurna nilai hambur balik gelombangnya (Lyzenga, 1981). Kendala lainnya adalah noise dari kolom atmosfer, sehingga perlu beberapa koreksi matematis sebelum citra diproses lebih lanjut.

Proses klasifikasi juga menjadi faktor penentu keberhasilan dari pemetaan. Pemilihan metode klasifikasi citra dengan tingkat akurasi yang baik juga menjadi pertimbangan (Mumby et al. 1999; Green et al. 2000; Congalton \& Green 2009). Klasifikasi citra saat ini dapat dilakukan dengan menggunakan metode klasifikasi berbasis piksel dan berbasis objek (Blaschke, 2010). Penerapan metode klasifikasi berbasis piksel yang umumnya menggunakan algoritma maximum likelihood telah menghasilkan peta zona geomorfologi dengan tingkat akurasi yang beragam. Sementara klasifikasi berbasis objek mampu mengkelaskan objek pada citra yang meliputi aspek spektral dan aspek spasial (Danoedoro, 2012). Klasifikasi berbasis objek ini merupakan proses segmentasi citra dari pixel level menjadi segmen/objek (object level) yang homogen dilihat berdasarkan parameternya.

Menyajikan peta terumbu karang yang akurat untuk memeriksa struktur biologis dan proses geomorfik merupakan tantangan besar dalam penginderaan jauh. Mendapatkan peta dengan akurasi yang baik diperlukan beberapa algoritma koreksi dan skema klasifikasi yang terbaik (Phinn et al. 2011). Pengembangan metode berbasis objek sesuai untuk klasifikasi citra dengan resolusi sedang sampai dengan resolusi tinggi (Whiteside \& Ahmad 2005). Klasifikasi berbasis objek saat ini terbukti mampu meningkatkan akurasi pada pemetaan tutupan lahan serta geomorfologi dan ekosistem terumbu karang (Whiteside \& Ahmad 2005; Phinn et al. 2011; Anggoro et al. 2015). Penerapan klasifikasi citra berbasis objek pada penelitian ini diharapkan mampu menghasilkan pemetaan dengan akurasi yang baik. 


\section{METODE PENELITIAN}

Posisi geografis Pulau Tunda terletak antara 5'48'35" - 5'49'30'LS dan 106'15'00" - 106017' 30"BT (Gambar 1). Pengamatan lapangan dilaksanakan di wilayah perairan Pulau Tunda Kabupaten Serang, Banten pada bulan Agustus 2014 dan Maret 2015.

\section{Bahan dan data}

Penelitian ini menggunakan Citra satelit Worldview-2 (akuisisi pada tanggal 25 Agustus 2013, proyeksi koordinat UTM zona 48S-WGS84). Citra Worldview-2 terdiri dari 9 kanal (panchromatic, coastal, blue, green, yellow, red, red-edge, NIR1 dan NIR2). Band multispektral citra Worldview-2 memiliki resolusi spasial $2 \mathrm{~m}$ dan pankromatik resolusi spasial $0.5 \mathrm{~m}$ (Digitalglobe, 2010). Pengamatan lapangan secara visual dilakukan untuk mengidentifikasi zona geomorfologi. Data batimetri digunakan saat mengidentifikasi zona geomorfologi. Data batimetri didapatkan dari Febrianto (2016).

\section{Tahapan penelitian}

Penelitian ini dilakukan dengan dua tahapan yaitu tahapan pengolahan citra dan tahapan pengamatan lapangan. Penelitian ini juga dilakukan proses uji akurasi untuk melihat tingkat keakuratan dari klasifikasi. Tahapan dari penelitian ini tertera pada (Gambar2).

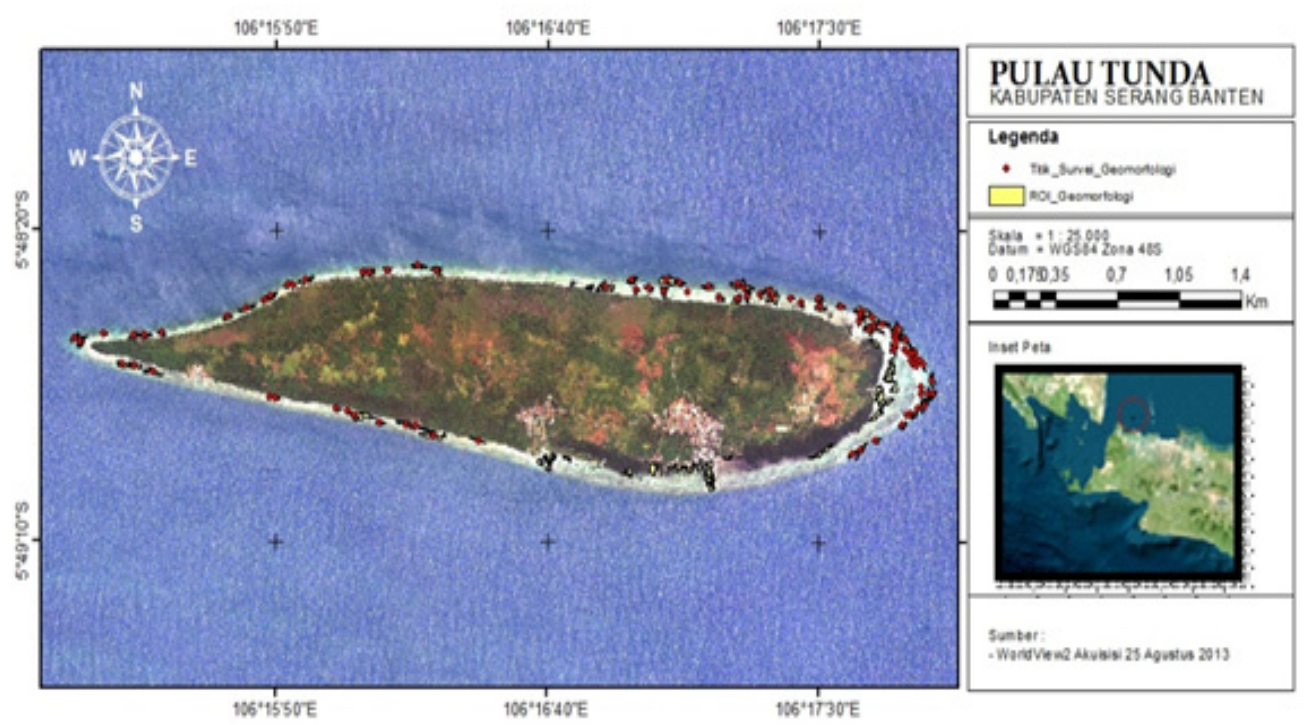

Gambar 1. Lokasi penelitian dan titik pengamatan lapangan (Citra Worldview-2 komposit RGB 531 Datum WGS84 Zona 48S)

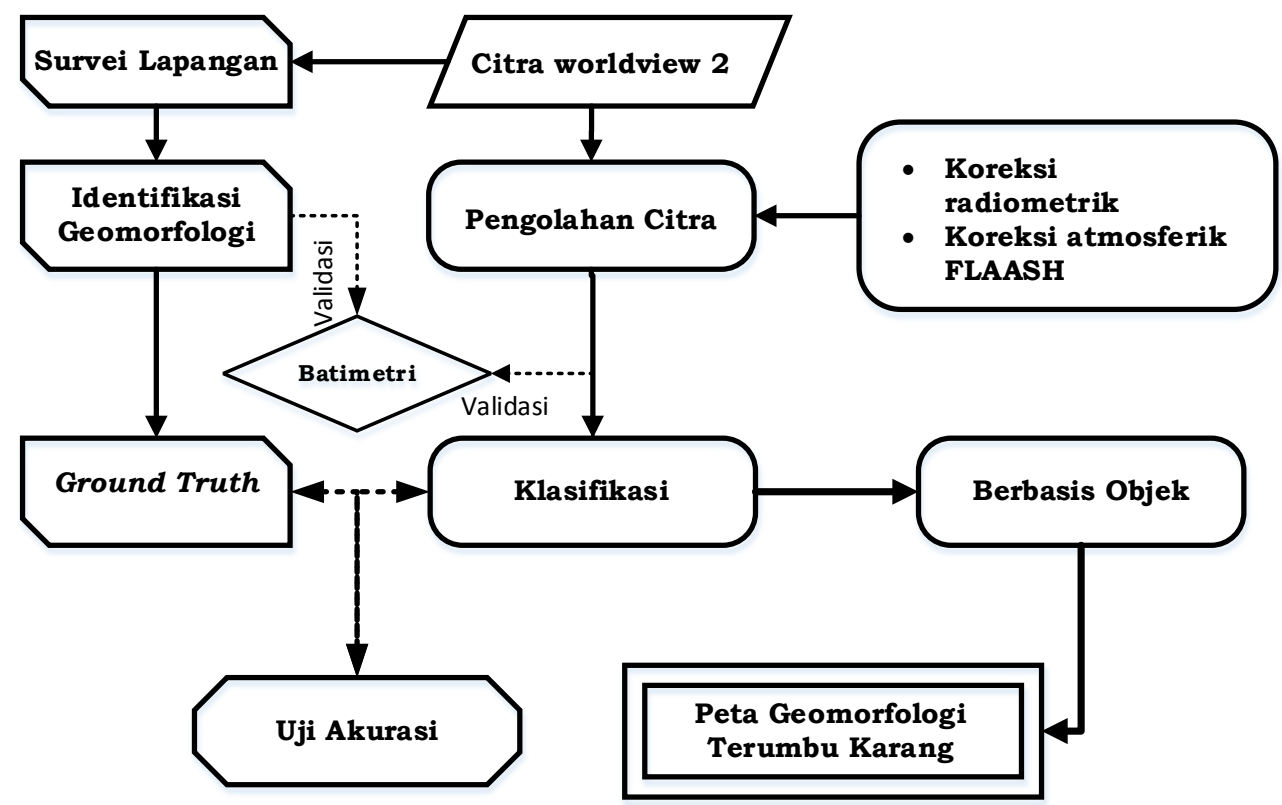

Gambar 2. Tahapan penelitian 
Koreksi citra

Koreksi atmosferik pada citra menggunakan model pada toolbox FLAASH (Fast Line-of-sight Atmospheric Analysis of Spectral Hypercube) yang telah tersedia pada perangkat lunak Envi 5.1. Modul FLAASH tersebut mampu menganalisis gelombang sinar tampak sampai inframerah rendah dari citra multispektral dan hiperspektral (Felde et al. 2003). Koreksi geometrik tidak dilakukan karena citra telah terkoreksi geometrik.

\section{Segmentasi}

Citra yang telah terkoreksi atmosferik menjadi Input Image Layer (IIL) dalam proses klasifikasi yang dilakukan di perangkat lunak Ecognition 9.0. Langkah pertama, dilakukan proses segmentasi IIL. Kedua, adalah proses klasifikasi masing-masing segmen menjadi kelas-kelas yang ditetapkan pada setiap level. Proses segmentasi menggunakan algoritma Multiresolution Segmentation (MRS). Algoritma tersebut merupakan pengatur homogenitas objek pada citra. Parameter dari algoritma MRS tersebut terdiri dari scale, shape, dan compactness. Scale adalah abstraksi untuk menentukan nilai maksimum dari heterogenitas objek yang dibangun. Shape adalah homogenitas tekstur dari IIL yang dikelompokkan berdasarkan nilai digital. Compactness berfungsi untuk mengoptimalkan kekompakan objekobjek yang berasal dari parameter shape (Trimble, 2014). Secara teoritis, saat ini masih belum ada formulasi dari parameter segmentasi terbaik untuk membangun objek yang diperlukan dalam proses klasifikasi. Pengguna harus melakukan uji try and error terhadap parameter-parameter segmentasi tersebut. Nilai scale dapat ditentukan menurut objek yang diperlukan pada setiap level (Blaschke \& Hay 2001, Burnett \& Blaschke 2003, Myint et al. 2011).

\section{Klasifikasi}

Citra yang telah tersegmentasi selanjutnya diklasifikasikan dengan cara membangun rule set klasifikasi di perangkat lunak Ecognition 9.0. Klasifikasi ditetapkan menjadi 2 level yang mengacu pada skema klasifikasi Phinn et al. (2011) yaitu klasifikasi level 1 (reef level) dan level 2 (zona geomorfologi). Klasifikasi Level 1 adalah proses pemisahan objek darat, perairan dangkal dan perairan dalam. Klasifikasi di level 2 bertujuan untuk mengkelaskan zona geomorfologi terumbu karang. Zona geomorfologi terumbu karang tersebut adalah:

- Reef Slope: zona perairan dangkal dengan tingkat kemiringan tertentu dan menghadap langsung ke arah perairan dalam.

- Reef Crest: zona puncak terumbu yang muncul pada saat surut terendah. Umumnya zona ini terletak pada bagian yang menghadap perairan dalam dan mendapat energi yang tinggi dari gempuran gelombang.

- Outer Reef Flat: wilayah di sekitar puncak terumbu yang menghadap perairan dalam sebelum lereng terumbu.

- Inner Reef Flat: wilayah di sekitar rataan terumbu yang dekat dengan daratan.

Klasifikasi dilakukan dengan cara menentukan nilai threshold dari fitur yang tepat untuk setiap kelas. Fitur yang digunakan terdiri dari fitur yang berhubungan dengan objek dan fitur yang berhubungan dengan kelas (Trimble, 2014). Aspek spektral adalah treshold dari nilai layer (mean, standart deviation, dan ratio antar kanal) dan kostumasi dengan transformasi NDVI (Normalize Different Vegetation Index). Aspek spasial adalah pengelompokan objekobjek yang telah memiliki kelas pada level yang sama ke dalam kelas hirarki objek citra seperti fitur relative boarder to. Algoritma klasifikasi dapat dilihat pada Tabel 1 .

Uji akurasi

Uji akurasi hasil klasifikasi pada penelitian ini menggunakan matrik kesalahan (error matrix/confusion matrix) dengan menghitung Overall Accuration (OA), Producer Accuracy (PA) dan User Accuracy (UA) (Congalton \& Green 2009). 
Tabel 1. Algoritma klasifikasi yang digunakan di Setiap Level

\begin{tabular}{lll}
\hline \multicolumn{1}{c}{ Level } & \multicolumn{1}{c}{ Kelas } & \multicolumn{1}{c}{ Algoritma klasifikasi } \\
\hline 1 (reef level) & Daratan & NDVI \\
& Perairan dalam & Mean band coastal \\
& Perairan dangkal & Mean band green \\
& Reef slope & Rel. border to perairan \\
& Reef crest & dalam \\
& Outer reef flat & Mean band blue \\
& Inner reef flat & Mean band green \\
& & Rel.border to daratan \\
\hline
\end{tabular}

\section{HASIL DAN PEMBAHASAN}

\section{Segmentasi multiresolusi}

Segmentasi level 1 menggunakan scale sebesar 200, shape 0.6 dan compactness 0.4 , sedangkan segmentasi level 2 menggunakan scale 30, shape 0.6 dan compactness 0.4 . Nilai dari segmentasi tersebut didapatkan melalui proses uji try and error dan hasil segmentasi tersebut dianggap telah mampu membangun dan memisahkan objek-objek yang menjadi kajian. Setiap level diterapkan nilai dari parameter scale, shape dan compactness yang berbeda beda. Nilai dari ketiga parameter tersebut ditentukan tergantung kebutuhan dan tingkat keditlan objek yang ingin diklasifikasi. Nilai skala pada level 1 tidak lebih besar dibandingkan pada level 2 sehingga objek yang dihasilkan pada level 2 lebih banyak dari level 1. Jumlah objek pada level 1 adalah sebanyak 2113 objek dan pada level 2 sebanyak 2206 objek. Wilayah yang heterogen pada citra menghasilkan objek yang lebih banyak dibandingkan wilayah yang homogen. Proses segmentasi IIL dapat dilihat pada Gambar 3.

\section{Klasifikasi level 1}

Hasil klasifikasi pada level 1 telah mampu mengkelaskan daratan, perairan dangkal, dan perairan dalam dengan baik (Gambar 4). Luas kelas daratan adalah $276.8 \mathrm{Ha}$, dan perairan dangkal seluas $85.1 \mathrm{Ha}$. Tingkat akurasi OA level 1 adalah sebesar 97\%. Akurasi PA dan UA setiap kelas dengan akurasi $>95 \%$. Klasifikasi pada level 1 dapat terpetakan dengan sangat baik dan menunjukkan batas-batas yang jelas pada masing masing kelas, namun masih terdapat beberapa kesalahan padaklasifikasi misalnya pada kelas perairan dangkal yang dikelaskan menjadi daratan. Faktor penyebabnya adalah objek terumbu karang seperti reef crest yang muncul ke permukaan perairan pada saat air surut sehingga terkelaskan menjadi objek darat. Klasifikasi pada level 1 (zona perairan dangkal) merupakan dasar layer untuk klasifikasi selanjutnya di level 2 yaitu klasifikasi zona geomorfologi perairan dangkal (Phinn et al. 2011).

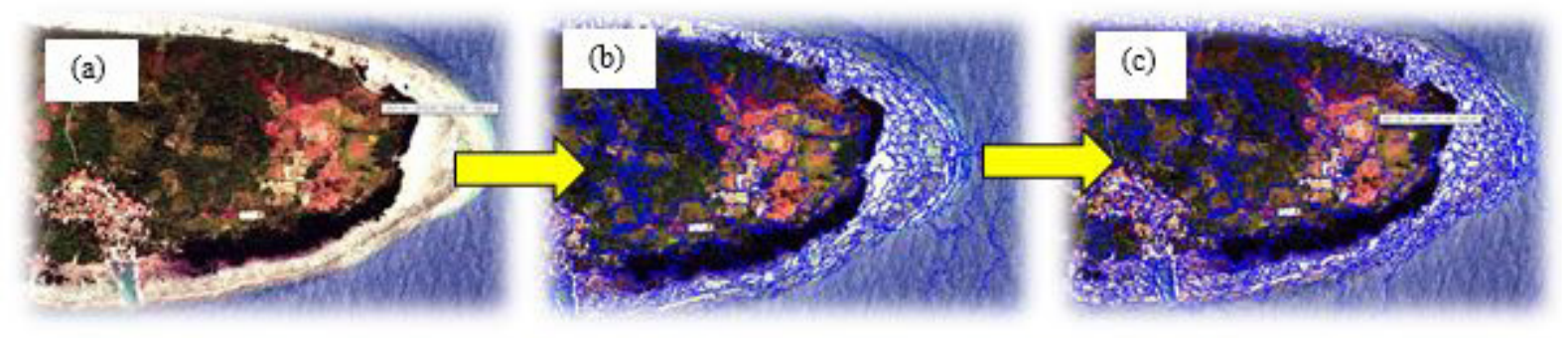

Gambar 3. Segmentasi pada setiap level: (a) Citra Worldview-2 koreksi atmosferik FLAASH komposit RGB (531); (b) Segmentasi level 1 (scale 200, shape 0.6 dan compactness 0.4); (c) Segmentasi level 2 (scale 30, shape 0.6 dan compactness 0.4) 


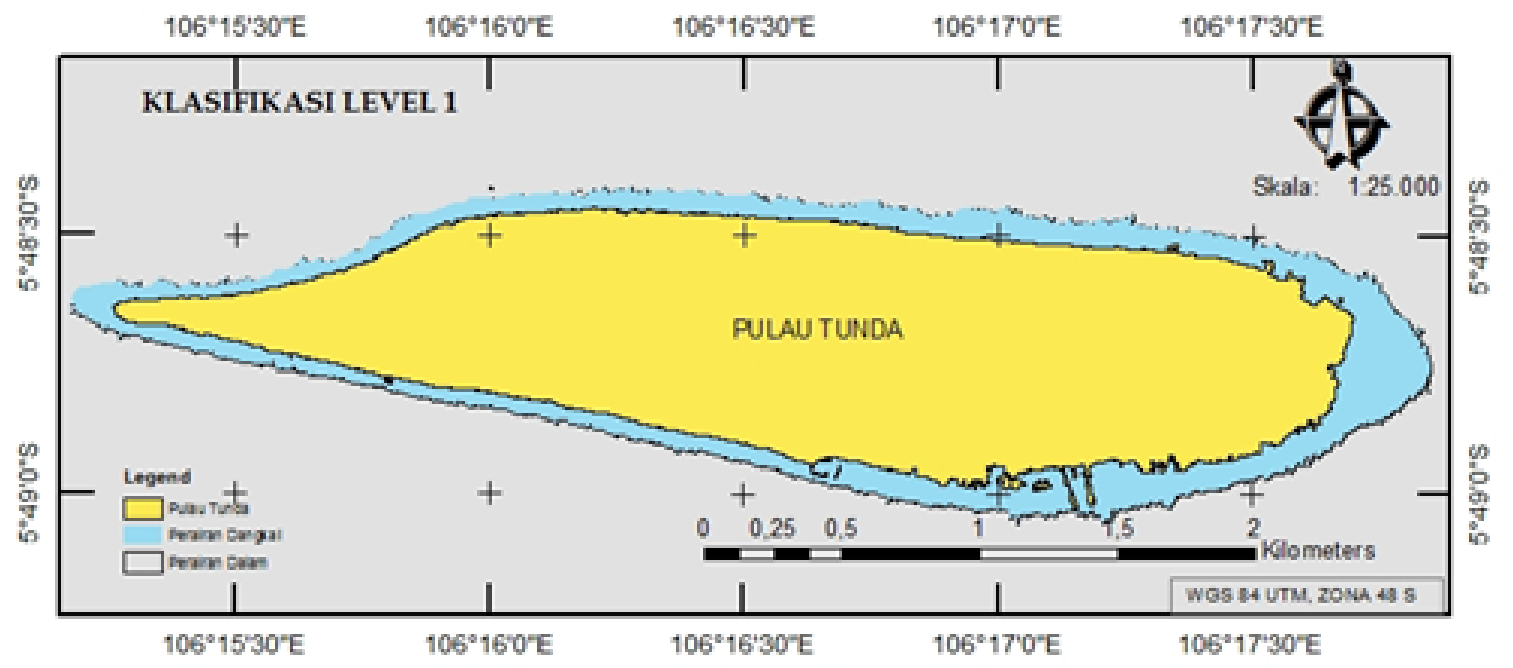

Gambar 4. Hasil klasifikasi level 1

\section{Klasifikasi level 2 (Zona Geomorfologi)}

Profil batimetri dijadikan dasar identifikasi zona geomorfologi terumbu karang, sehingga pada klasifikasi level 2 ini didapatkan 4 kelas meliputi reef slope, reef crest, inner reef flat dan outer reef flat. Profil batimetri ini sangat membantu untuk mengidentifikasi batas setiap zona geomorfologi untuk proses klasifikasi.

Nilai batimetri perairan Pulau Tunda berkisar antara $0.9 \mathrm{~m}-52.0 \mathrm{~m}$ (Febrianto, 2016). Perairan bagian timur laut sampai mengarah ke tenggara terdapat topografi perairan yang sangat rata hingga mencapai lebih dari $300 \mathrm{~m}$ dari bibir pantai (zona reef flat). Sampel profil batimetri dapat dilihat pada Gambar 5.

Zona geomorfologi yang dapat dikelaskan pada klasifikasi level 2 adalah 4 kelas yaitu: reef slope, reefcrest, inner reefflat dan outer reef flat (Gambar 6). Luas masingmasing kelas adalah: zona inner reef flat, 7.3 Ha; zona outer reef flat, $55.8 \mathrm{Ha}$; zona reef slope, $21 \mathrm{Ha}$; zona reef crest, $1 \mathrm{Ha}$. Diketahui bahwa zona outer reef flat mendominasi di perairan dangkal Pulau Tunda, sedangkan luasan terendah pada zona reef crest.

Nilai OA pada level 2 menunjukkan hasil akurasi yang tinggi yaitu sebesar 91\% (Tabel 2). PA dan UA bervariasi antara 74\%$100 \%$. PA terendah pada kelas reef slope sebesar $74 \%$. UA tertinggi pada kelas zona inner reef flat sebesar $100 \%$ menunjukkan bahwa pada kelas ini sangat homogen sehingga dapat dikelaskan dengan sangat baik.

Pemetaan zona geomorfologi terumbu karang yang telah banyak dilakukan menghasilkan nilai akurasi yang beragam dengan jumlah kelas yang berbeda-beda tergantung pada kompleksitas objek studi dan metode klasifikasi yang dipilih. Menurut Andrefouet et al. (2003) akurasi pemetaan akan menurun berbanding lurus dengan semakin kompleksnya objek yang dikaji dan semakin banyak jumlah kelas klasifikasi. Green et al. (2000) menyatakan bahwa akurasi pemetaan habitat bentik yang ideal adalah dengan akurasi keseluruhan sebesar $>60 \%$. Faktor yang mempengaruhi rendahnya akurasi disebabkan kompleksitas bentukan zona geomorfologi yang tinggi di wilayah kajian. Pemetaan zona geomorfologi yang menggunakan klasifikasi berbasis objek telah dilakukan oleh beberapa peneliti seperti Phinn et al. (2011), melaporkan bahwa penelitian pada zona geomorfologi yang dilakukannya menghasilkan akurasi pemetaan $>80 \%$. Roelfsema et al. (2013) melaporkan hasil akurasi pemetaan berbasis objek pada pemetaan zona geomorfologi diperoleh akurasi keseluruhan antara $76 \%-82 \%$. Penelitian yang dilakukan oleh Zhang et al. (2013) yang menggunakan klasifikasi berbasis objek menghasilkan akurasi keseluruhan tertinggi yaitu 86.3\% dari keseluruhan percobaan terhadap citra. Pada lokasi yang berdekatan dengan Pulau Tunda, yaitu pemetaan berbasis objek yang dilakukan oleh Anggoro et al. (2015) menghasilkan pemetaan geomorfologi terumbu karang Pulau Pari dengan akurasi yang tinggi yaitu $87 \%$.

Penerapan klasifikasi berbasis objek sesuai untuk penerapan pemetaan geomorfologi terumbu karang yang dikombinasikan dengan pengamatan 
lapangan dan validasi terhadap data batimetri. Keunggulan dari metode ini adalah mampu menghubungkan aspek spektral dan spasial sekaligus. Namun, hasil pemetaan dengan metode ini masih belum maksimal karena tidak bakunya formulasi dan kerangka dari parameter segmentasi di setiap objek yang akan dikaji. Sehingga diperlukan uji try and error secara mandiri terhadap parameter-parameter segmentasi di setiap level yang dibangun.
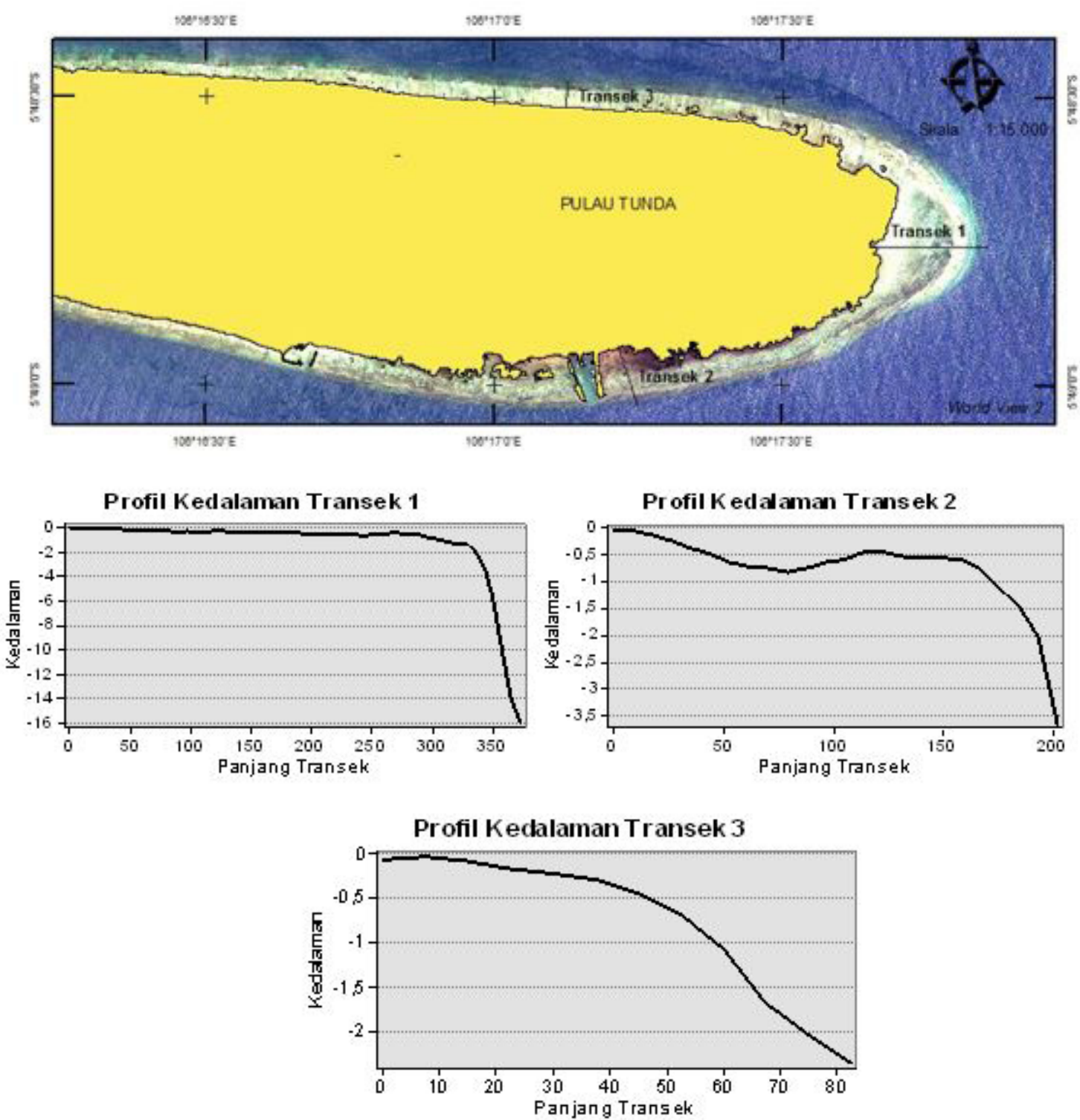

Gambar 5. Sampel profil batimetri perairan Pulau Tunda yang selanjutnya digunakan untuk validasi zona geomorfologi secara kontekstual 


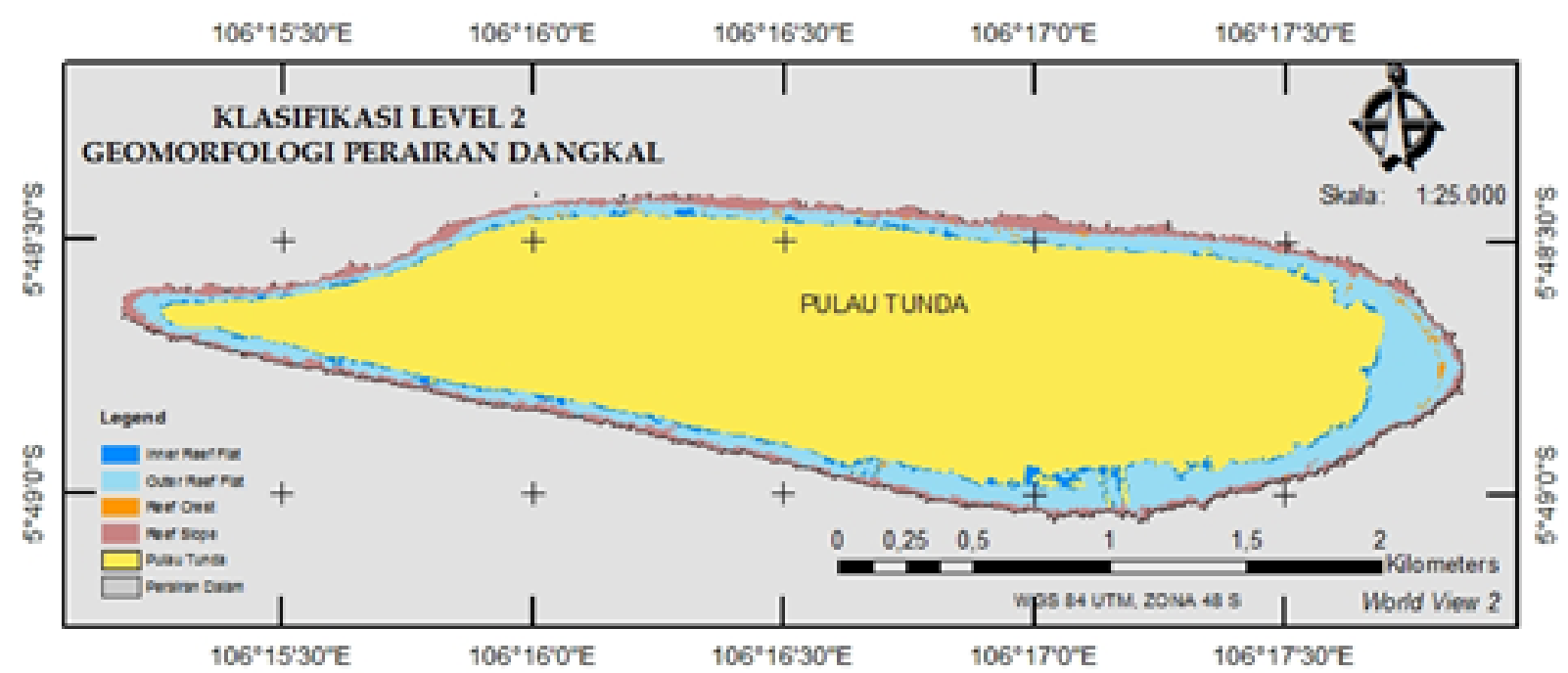

Gambar 6. Klasifikasi level 2 (zona geomorfologi)

Tabel 2. Uji akurasi level 2

\begin{tabular}{lcccccc}
\hline \multirow{2}{*}{ Citra } & \multicolumn{7}{c}{ Lapang } \\
\cline { 2 - 6 } & $\begin{array}{c}\text { Inner Reef } \\
\text { Flat }\end{array}$ & $\begin{array}{c}\text { Outer Reef } \\
\text { Flat }\end{array}$ & $\begin{array}{c}\text { Reef } \\
\text { Crest }\end{array}$ & $\begin{array}{c}\text { Reef } \\
\text { Slope }\end{array}$ & Total & UA \\
\hline $\begin{array}{l}\text { Inner Reef } \\
\text { Flat }\end{array}$ & 7 & 0 & 0 & 0 & 7 & $100 \%$ \\
Outer Reef & 0 & 42 & 0 & 8 & 50 & $84 \%$ \\
Flat & & 0 & 11 & 0 & 11 & $100 \%$ \\
Reef Crest & 0 & 0 & 0 & 23 & 23 & $100 \%$ \\
Reef Slope & 0 & 42 & 11 & 31 & 91 & \\
Total & 7 & $100 \%$ & $100 \%$ & $74 \%$ & OA: & $91 \%$ \\
PA & $100 \%$ & & & & & \\
\hline
\end{tabular}

\section{KESIMPULAN}

Penerapan klasifikasi berbasis objek pada citra Pulau Tunda menghasilkan 4 kelas klasifikasi. Kelas-kelas tersebut adalah zona inner reef flat seluas $7.3 \mathrm{Ha}$; zona outer reef flat seluas $55.8 \mathrm{Ha}$; zona reef slope seluas $21 \mathrm{Ha}$ dan zona reef crest seluas $1 \mathrm{Ha}$. Nilai Overall accuracy level 1 sebesar 97\% dan level 2 sebesar 91\%. Berdasarkan nilai akurasi yang tinggi tersebut maka dapat disimpulkan bahwa klasifikasi citra berbasis objek di daerah Pulau mendapatkan akurasi yang tinggi.

\section{UCAPAN TERIMA KASIH}

Penulis mengucapkan terima kasih kepada Try Febrianto atas kontribusi data batimetri dan tim penelitian Pulau Tunda yaitu Tarlan Subarno, Nunung Noer Aziizah dan Ike Dori Chandra.

\section{DAFTAR PUSTAKA}

Andrefouet S, et al. 2003. Multi-site Evaluation of Ikonos Data for Classification of Tropical Coral Reef Environments. Remote Sens. Environ. 88: 128-143.

Andrefouet S, Muller-Karger FE, Hochberg EJ, Hu C, Carder KL. 2001. Change Detection in Shallow Coral Reef Environments using Landsat 7 ETM+ Data. Remote Sens. Environ. 78: 150162.

Anggoro A, Siregar VP, Agus SB. 2015. Pemetaan Zona Geomorfologi Ekosistem Terumbu Karang Menggunakan Metode OBIA. Jurnal Penginderaan Jauh 12 (1): 1-12

Asriningrum W. 2005. Studi Identifikasi Karakteristik Pulau Kecil Menggunakan Data Landsat dengan Pendekatan Geomorfologi dan Penutup Lahan 
(Studi Kasus Kepulauan Pari dan Kepulauan Belakang Sedih) Surabaya: Pertemuan Ilmiah Tahunan MAPIN XIV.

Blakeway D, Hamblin MG. 2015. SelfGenerated Morphology in Lagoon Reefs. PeerJ 3:e935; DOI 10.7717/peerj.

Blanchon P. 2011. Geomorphic Zonation, Netherlands: Encyclopedia of modern coral reefs, Springer. Pages 469-486 in Hopley D, ed.

Blaschke T, Hay GJ. 2001. Object-Oriented Image Analysis and Scale-Space: Theory and Methods for Modeling and Evaluating Multiscale Landscape Structure. Isprs A Photogramm 34: 2229.

Blaschke T. 2010. Object Based Image Analysis for Remote Sensing. Isprs $J$. Photogramm. 65: 2-16.

Burnett C, Blaschke T. 2003. A Multi-Scale Segmentation/object Relationship Modelling Methodology for Landscape Analysis. Ecol. Model 168: 233-249.

Chauvad S, Bouchon C, Maniere R. 1998. Remote Sensing Techniques Adapted to High Resolution Mapping of Tropical Coastal Marine Ecosystems (Coral Reefs, Seagrass Beds and Mangrove). Int. J. Remote Sens. 19(18): 3625-3639.

Congalton RG, Green K. 2009. Assessing the Accuracy of Remotely Sensed Data-Principles and Practices (second edition). Boca Raton: CRC Press.

Danoedoro P. 2012. Pengantar Penginderaan Jauh Digital. Yogyakarta (ID): ANDI Press.

Digitalglobe. 2010. Radiometric Use of Worldview-2 Imagery: Technical note. 1601 Dry Creek Drive Suite 260 Longmont, Colorado (USA) 80503: DigitalGlobe $\AA$.

Direktorat Jenderal Kelautan Pesisir dan Pulau Pulau Kecil Kementerian Kelautan dan Perikanan [Dirjen KP3KKKP]. 2012. Identifikasi Pulau Pulau Kecil, Jakarta: Direktorat Jenderal Kelautan Pesisir dan Pulau Pulau Kecil Kementerian Kelautan dan Perikanan.

Febrianto T. 2016. Kombinasi Data Akustik dan Satelit untuk Pemetaan Batimetri di Perairan Dangkal Pulau Tunda. [Tesis]. Bogor: Fakultas Perikanan dan Ilmu Kelautan IPB.

Felde GW, Anderson GP, Cooley TW, Matthew MW, Adler-Golden SM, Berk A, Lee J. 2003. Analysis of Hyperion Data with the FLAASH Atmospheric Correction Algorithm. IEEE IGARSS: Learning from Earth's Shapes and Colours; Toulouse.p 90-92.

Green EP, Mumby PJ, Edwards AJ, Clark CD, 2000. Remote Sensing Handbook for Tropical Coastal Management. France: UNESCO.

Leon J, Phinn SR, Woodroffe CD, Hamylton S, Roelfsema C, Saunders M. 2012. Data Fussion for Mapping Coral Reef Geomorphic Zones: Possibilities and Limitation. Rio de Jeneioro: Proceedings of the 4th Geobia.

Lillesand TM, Kiefer RW, Chipman JW. 2004. Remote Sensing and Image Interpretation. United State of America: John Wiley and Son.

Lyzenga DR. 1981. Remote Sensing of Bottom Reflectance and Water Attenuation Parameters in Shallow Water using Aircraft and Landsat Data. Int J Remote Sens. 2: 71-82.

Maeder J, Narumalani S, Rundquist DC, Perk RL, Schalles J, Hutchins K, Keck J. 2002. Classifying and Mapping General Coral-Reef Structure Using Ikonos Data. Photogrammetric Engineering and Remote Sensing 68(12): 12971306.

Mumby PJ, Green EP, Edwards AJ, Clark CD. 1999. The Cost-Effectiveness of Remote Sensing for Tropical Coastal Resources Assessment and Management. $J$ Environ Manage. 55: 157-166.

Myint SW, Gober P, Brazel A, GrossmanClarke S, Weng Q. 2011. Per-Pixel vs Object-Based Classification of Urban Land Cover Extraction using High Spatial Resolution Imagery. Remote Sens Environ. 115(5): 1145-1161.

Navulur K. 2007. Multispectral Image Analysis using the Object-oriented Paradigm. LLC: Taylor \& Francis Group.

Phinn SR, Roelfsema CM, Mumby PJ. 2011. Multi-scale, Object-based Image Analysis for Mapping Geomorphic and Ecological Zones on Coral Reefs. Int $J$ Remote Sens 33: 3768-3797.

Roelfsema C, Phinn S, Jupiter S, Comley J, Albert S. 2013. Mapping Coral Reefs at Reef to Reef-system Scales, 10s-1000s $\mathrm{km} 2$, using object-based image analysis. Int $J$ Remote Sens 34: 6367-6388.

Tamondong AM, Blanco AC, Fortes MD, Nadaoka K. 2013. Mapping of Seagrass and Other Benthic Habitats in Bolinao, Pangasinan using Worldview 2 Satellite Image. Geoscience and 
Remote Sensing Symposium (IGARSS): IEEE International. 1579-1582

Trimble. 2014. Ecognition Developer: User Guide. Munich [Germany]: Trimble.

Whiteside T, W Ahmad. 2005. A Comparison of Object-Oriented and Pixel Based Classification Methods for Mapping Land Cover in Northern Australia. Melbourne: Proceedings of SSC (The National biennial Conference of the Spatial Science Institute).

Zhang C, Selch D, Xie Z, Roberts C, Cooper
H, Chen G. 2013. Object-based Benthic Habitat Mapping in the Florida Keys from Hyperspectral Imagery. Estuar. Coast. Shelf S. 134: 88-97.

Zhi-gang L, Jing L, Boon-Leong L, Cungyueh S, Suppiah I, Zhicao S. 2008. Local Spatial Statistics for Remotely Sensed Image Classification of Mangrove. Remote Sensing and Spatial Information Sciences 37: 719-724. 